monitor the outcome of the $\mathrm{Rh}$ prophylaxis programme, the time may be right to investigate circumstances leading to cases of infants affected by $R h$ haemolytic disease rather than deaths. This is especially important if the death rate is falling while new cases are still occurring at the same rate. Computerised blood transfusion centres could provide information to interested clinicians about new cases occurring. This could be a topic for a regional obstetric audit group.

In summary, we think that the overall outlook for almost complete prevention of $\mathrm{Rh}$ haemolytic disease deaths is good. The introduction of monoclonal anti-D is on the horizon and, when it is readily available, will contribute to a reduction in new cases of sensitisation.
We are grateful to Professor P L Mollison for advice on the classification of cases, and Professor Charles Rodeck and Dr L A D Tovey for commenting on the changing rates of death in 1988 and 1989. The Office of Population Censuses and Surveys kindly forwarded the death information and Mrs E Batty typed the manuscript. The work is supported by the Mersey Regional Research Committee.

1 Clarke CA, Mollison PL. Deaths from Rh haemolytic disease of the fetus and newborn, 1977-87. $7 R$ Coll Physicians Lond 1989;23:181-4

2 US Department of Health, Education and Welfare, National Center for Health Statistics. Vital statistics of the United States. Vol 2. Mortality, Part A Hyattsville, Maryland: DHEW, 1956-87.

3 Thomson A, Contreras M, Gorick B, Kumpel B, Chapman GE, Lane RS, et al. Clearance of Rh D-positive red cells with monoclonal anti-D. Lance 1990;336:1147-50.

(Accepted 24 April 1991)

\section{Portable medical record for the homeless mentally ill}

\author{
James B Reuler, John R Balazs
}

\section{Section of General \\ Medicine, Department of \\ Veterans Affairs Medical Center, Portland, Oregon, USA \\ James B Reuler, MD, associate professor}

\section{East London Homeless Health Project, London John R Balazs, MRCGP,} general practitioner

Correspondence to: Dr John Balazs, The Surgery, 1 Binfield Road, London SW4 6TB.

BMf 1991;303:446 held medical record was studied.

\section{Methods and results}

Among homeless people those who are chronically mentally ill pose challenges for health care delivery systems. With a high prevalence of repeated psychiatric admissions homeless mentally ill patients may see many health care providers who are unfamiliar with their past care. Information about the past history of homeless chonically mentally ill patients might help primary care providers institute more timely management. To test the hypothesis that a medical record carried by the patient might obviate some of the problems related to care for homeless mentally ill people the use of a patient

A portable record utilising pulpboard covers and Polyart 2 untearable paper was designed. Record dimensions were $13.5 \times 8 \mathrm{~cm}$. Homeless chronically mentally ill patients who were receiving care through the East London Homeless Health Project or residents of the Salvation Army Hopetown Hostel receiving on site care by a psychiatric nurse from the London Hospital, St Clement's, were recruited between April 1988 and April 1989. Once identified as a study subject the patient had his or her regular medical record flagged to indicate study participation and was given a portable record containing personal and medical information. On return visits the patient was asked questions about the portable record and, when available, the record itself was reviewed by the provider. The study was approved by the Tower Hamlets District ethics committee.

Of 61 patients asked to participate, 41 agreed. Follow up information was available for 28 of these 41 subjects ( 17 women, 11 men; average age 41.3 years). Schizophrenia was the primary diagnosis in 28 cases. Thirty patients were currently receiving medication for psychiatric disorders, and 25 stated that they were registered with a general practitioner in London.

Twenty eight patients with at least one follow up visit accounted for a total of 67 follow up interviews. At only five of the 28 follow up visits for women, as compared with 24 of the 39 for men, was the record available for review. The most common reason given for failing to bring the chart to the visit was that the patient had forgotten or that it had been stolen. At 33 follow up visits the patient reported that another provider had been seen, including general practitioners, accident and emergency room staff, psychiatrists, lawyers, police, social workers, and district nurses. In 26 instances the patients stated that the portable record had been given to the other provider. Of the 28 patients with follow up visits, all but three had read the portable record and only one expressed anger after reviewing the information. Review of the records at follow up visits showed that there was new information recorded in eight. Two records were returned by mail.

\section{Comment}

Recent recommendations of an advocacy group for homeless people included a statement that they should carry a copy of a modified medical record. 'Although the concept of a medical record carried by the patient is not new, ${ }^{2}$ there are no reports of its use among homeless people.

The results of our study of a portable medical record for a subgroup of the homeless population are limited because only $28(68 \%)$ of the subjects enrolled were seen for follow up. Nevertheless, several conclusions can be drawn. Firstly, this pilot project shows that having a patient held medical record is feasible for homeless people. Patients who were seen at follow up demonstrated the ability to carry this small record, and several patients who failed to bring the portable medical record to follow up visits acknowledged that it was still in their possession. It is reasonable to expect that homeless patients who are not chronically mentaly ill will have a higher compliance rate with the use of a portable record.

Secondly, the utility of the portable record was confirmed: it was presented to other types of providers, who received a certain amount of basic information and a contact for future coordination of care. Several portable records contained entries by some of these providers which included new information not previously available.

Finally, this group of mentally ill patients found pleasure in reading their medical records. Greatest concern about patient access to medical records has centred on psychiatric patients, ${ }^{3}$ but studies of their response to record review have not shown adverse effects. ${ }^{45}$ Our findings suggest that a patient held medical record for homeless chronically mentally ill people could be used safely.

1 Health Sub-Group, Joint Working Party on Single Homelessness in London. Primary health care for homeless single people in London: a strategic approach. London: SHIL Health Sub-Group, 1987.

2 Baldry M,Cheal C, Fisher B, Gillett M, Huet V. Giving patients their own records in general practice: experience of patients and staff. $B M J 1986 ; 292: 596-8$.

Priest RG. Da Protection Act: subject access to personal health information Priest RG. Data Protection Act: subject access to personal health information (DA8523): DHSS consult

4 Roth LH, Wolford J, Meisel A. Patient access to records: tonic or toxin? Am f Psychiatry 1980;137:592-6.

5 Parrott J, Strathdee G, Brown P. Patient access to psychiatric records: the patient's view. J $R$ Soc Med 1988;81:520-2.

(Accepted 10 May 1991) 